\title{
The Effects of Hybrid Learning and Flipped Classroom Methods in Increasing the Learning Independence of Students' Citizenship Course
}

\author{
Prihma Sinta Utami ${ }^{1 *}$, Muhibuddin Fadhli ${ }^{1}$
}

\author{
${ }^{1}$ Universitas Muhammadiyah Ponorogo, Ponorogo, Indonesia \\ *Corresponding author. Email: prihmasinta@gmail.com
}

\begin{abstract}
This study aims to determine the significance of the difference between the use of hybrid learning and flipped classroom methods in increasing the learning independence of student citizenship at Universitas Muhammadiyah Ponorogo. This research uses quantitative methods with quasi-experimental type (quasi experiment). The results show that the value of $t$ score $>t$ table that is $t=2.54$ is greater than the table $0.025=$ 1.99 then $\mathrm{H}_{0}$ is rejected. This means that $\mathrm{H} 0$ is rejected, and $\mathrm{Ha}$ is accepted, meaning that there is a significant difference between the hybrid learning method and the flipped classroom in increasing the learning independence of student citizenship. The hybrid learning method contributes more significantly to the independence of student citizenship learning than flipped classrooms. This can be seen from the percentage increase in the results of the questionnaire independence for student citizenship learning, for classes taught with the hybrid learning method gained an increase of $21.03 \%$ while for classes taught with flipped classrooms an increase of $13.89 \%$. In addition to being seen from the results of the questionnaire, based on the results of the student citizenship learning test showed the percentage of students who achieved the passing grade criteria for classes taught with the hybrid learning method was $82.85 \%$ while the class taught with flipped classroom was $74.28 \%$.
\end{abstract}

Keywords: hybrid learning, flipped classroom methods, learning independence, students' citizenship

course

\section{INTRODUCTION}

The learning process in the digital era should be able to implement innovation and among other things, utilize technology through hybrid learning method. People in the world have widely used this innovative pedagogical approach. Therefore, learning with hybrid learning method faces various challenges, especially for developing countries. One of the biggest challenges is about how students can successfully use technology and ensure students' sincerity to learning according to their learning characteristics when they use technology [1]. He believes that when students have difficulty using technology, it is likely that they will leave the learning. Learning as good as anything still requires participation from students, so to overcome their boredom in learning is the primary concern in this study.

In a report conducted by the Oxford Groups, [2] some students $(16 \%)$ had a negative attitude towards hybrid learning, while about $26 \%$ of students were worried they could not complete their learning using hybrid learning. Even so, several studies provide a different picture of this learning method, call it research conducted by De jong [3] he argues that when learning Hybrid Learning through variations in learning approaches in the classroom based on student-centred learning can create collaborative learning. This opinion is supported by Andrea \& Holbrok [4] according to them in the Microbiology lesson that they are able to some students feel worried because the intensity of face to face with the teacher reduced in learning hybrid learning, however, the results of the study indicate that the concern is a turning point in the learning process because students are accustomed to managing the learning process in accordance with a predetermined schedule, so that children are more independent and independent learning is formed.

In this research, the hybrid learning method will be juxtaposed with the flipped classroom method. The flipped classroom is a reversal of traditional learning procedures, which is usually done in the classroom in traditional learning to be carried out at home in a flipped classroom. In traditional learning, students are taught the subject matter by the teacher in class (through lectures or direct explanations from the teacher, group discussions, or reading and observing), then doing assignments for reinforcement at home (in the form of homework).

In a flipped classroom, students learn subject matter at home (through watching learning videos, making summaries, taking notes on important points, making questions, discussing with friends online, or reading the resources needed). In the class, there are also discussions, laboratory practices, explanations of concepts that are not yet understood by students, but this is for reinforcement or deepening. In their book Flip Your Classroom: Reach Every 
Student in Every Class Everyday [5], Jonathan Bergmann and Aaron Sams write "Basically the concept of a flipped class is this: that which is traditionally done in class is now done at home, and that which is traditionally done as homework is now completed in class ".

The presentation of the two methods above and the author's observations about the low achievement scores of citizenship courses and the right techniques should be sought to stimulate learning independence with both ways. So that later, the results obtained become our benchmark to provide the right approach for students. This study aims to determine the significance of the difference between the use of hybrid learning and flipped classroom methods in increasing the learning independence of student citizenship at Universitas Muhammadiyah Ponorogo.

\section{METHOD}

The study was conducted using quasi-experimental methods. This research is quasi-experimental because the researcher does not control all the external variables that influence the implementation of the experiment. The purpose of this study is to determine the differences in increasing student learning independence in citizenship courses, between classes taught by hybrid learning methods and classes taught by flipped classroom methods.
The research design used in this study was to use a Randomized Subject, Pre-test - Post-test Group Design.

Table 1 Research Design

\begin{tabular}{|cccc|}
\hline Groups & Pre-test & Treatment & Post-test \\
\hline Experiment 1 & $\mathrm{Y}_{1}$ & $\mathrm{Ta}$ & $\mathrm{Y}_{2}$ \\
Experiment 2 & $\mathrm{Y}_{1}$ & $\mathrm{~Tb}$ & $\mathrm{Y}_{2}$ \\
\hline
\end{tabular}

explanation:

$\mathrm{Y}_{1}=$ Questionnaire and Preliminary Observation

$\mathrm{Ta}=$ Treatment with hybrid learning method

$\mathrm{Tb}=$ Treatment with flipped classroom method

$\mathrm{Y}_{2}=$ Questionnaire, final observation, Test

\section{RESULTS AND DISCUSSION}

The results of an experimental study using two learning methods and the flipped classroom method indicate differences in the increase in student learning independence of citizenship. The results of the calculation of the independent sample t-test for the two groups in terms of the increase in the results of observations increased student learning independence presented in Table 2

Table 2 T-test results differences in standard gain

\begin{tabular}{|llllll|}
\hline \multirow{2}{*}{ Value } & $\boldsymbol{F}$-test & & \multicolumn{3}{c|}{ T-test } \\
\cline { 2 - 6 } & $\boldsymbol{F}$ & $\boldsymbol{S i g}$ & $\boldsymbol{t}$ & $\boldsymbol{d f}$ & Sig \\
\hline Standard Gain & 1.80 & 0.18 & 2.54 & 68 & 0.01 \\
& & & 2.54 & 65.67 & 0.01 \\
\hline
\end{tabular}

The value of $t$ standard gain for the same variance is 2,54 with a significance level of 0.01 . Based on the $0.025 \mathrm{t}$ table, the value of $t$ for $\mathrm{df}=68$ is 1.99 . The results show that the value of $t$-score $>$ ttable that is t-score $=2,54$ is greater than t-table $0.025=1.99$ then $\mathrm{H} 0$ is rejected. The significance level of the calculation is 0,01 , whose value is smaller than 0.05 ( $\mathrm{p}<0.05)$. These means that $\mathrm{H} 0$ rejected, and $\mathrm{Ha}$ is accepted, meaning that there is a difference in student learning independence between students who are given learning by the hybrid learning method and flipped classroom. Hybrid learning is one part of Massive Open Online Coursewares (MOOCs) where this method has been widely used in several countries. One of the results of research that says that this method is also able to increase student understanding is research from Alammary [6], he implemented a systematically reviews about the implementation of hybrid learning in several countries. This research measures the effect size (ES) of each subject that has been affected by the hybrid learning method. As a result, this research shows that the hybrid learning method has many different styles of implementation, one of which is the flipped classroom, however the application of the flipped classroom method has its characteristics that differ from the hybrid learning method. Other results from this research indicate that this method is effective in impacting students who use it.

\section{CONCLUSION}

The Learning process by applying hybrid learning methods tackle the challenges of technology implementation in the disruption era. In this research, the writer deliberately controls the variables to be equal, so there is no tendency that the writer proposes more than one method. In one hand, the data suggests a fact that Hybrid learning method is more significant in giving effect compared to the flipped classroom method. This is based on the ability of students to accept material presented through their learning management systems can be well absorbed. On the other hand, the Flipped classroom method even though it has a smaller effect than the hybrid learning method, but this method is also quite effective in giving influence to the study of citizenship courses.

The results show that the value of $\mathrm{t}$ score $>\mathrm{t}$ table that is $\mathrm{t}=$ 2.54 is greater than the table $0.025=1.99$ then Ho is rejected. According to these results the Hybrid learning method has a role in making a positive contribution in supporting literacy movements by students, they can access information anywhere and anytime, both synchronous and asynchronous. 
[3] N. de Jong, M. Savin-Baden, A. M. Cunningham,

The pros of this method are the presence of face-to-face activities to perfect the online meeting. Thus, the role of educators will not be replaced and interactions with students will be maintained. This method gives students independence in accessing information and bridging their learning styles. In addition, the use of appropriate teaching materials from the research results also supports the success of the implementation of this method, compared to the Flipped classroom method students are more flexible in utilizing learning materials and content to support the success of learning achievement.

\section{REFERENCES}

[1] J. Hofmann, "Top 10 Challenges of Blended Learning," Soapbox, 2011.

[2] C. J. Bonk and C. R. Graham, "Blended LearningCurrent Use, Challenges and Best Practices Report 2013," in Chapter 2: Language Basic, 2005. and D. M. L. Verstegen, "Blended learning in health education: three case studies," Perspect. Med. Educ., vol. 3, no. 4, pp. 278-288, 2014, doi: 10.1007/s40037014-0108-1.

[4] A. Edginton and J. Holbrook, "A Blended learning approach to teaching basic pharmacokinetics and the significance of face-to-face interaction," Am. J. Pharm. Educ., 2010, doi: 10.5688/aj740588.

[5] B. F. Hantla, "Book Review: Flip your classroom: Reach every student in every class every day.," Christ. Educ. J. Res. Educ. Minist., 2014, doi: 10.1177/073989131401100120.

[6] A. Alammary, "Blended learning models for introductory programming courses: A systematic review," PLoS One, vol. 14, no. 9, pp. 1-26, 2019, doi: 10.1371/journal.pone.0221765. 